\title{
Lagerstroemia indica 1 . high potential medicinal plant in introduction conditions of kashkadarya
}

\author{
Sharonova Mohidil Amanovna \\ A teacher of \\ Karshi State University \\ Rashit Rakhimovich Rakhmonov \\ Assistant Teacher (PhD) \\ Bukhara State Medical Institute \\ Zulfikarov Abdurayim Naimovich \\ Candidate of biological sciences \\ Associate professor of \\ Bukhara State Medical Institute
}

\begin{abstract}
LAGERSTROEMIA INDICA L. has anti-inflammatory, analgesic, antipyretic, antioxidant, anticancer, antimicrobial, Alzheimer's, antidiabetic, hepatoprotective and antithrombin effects. 1,3,5Trimethylbenzene, n-Undekan, Pelargonaldehyde, n-Dodekan, 1,1-Dibutoxibutane, Triacetylglycerin, 4,4,7a-trimethyl-5,6,7,7a-tetrahydrobenzofuran-2 (4H) -on, tsis-Pinan, neophytadiene, chlorpyrifos, alkaloids, cardiac glycosides, tannins, saponins, sterols, triterpenes, anthraquinones, reducing compounds, flavonoids (flavanones / dihydroflavonols and chalcones) and phenolic glycosides. This article discusses the chemical composition, components, and pharmacological effects of Indian lagerstroemia indica $L$.
\end{abstract}

Key words: Indian camphor, pharmacology, ingredients, components, importance. Introduction, cholecystitis, flavonoids, cholesterol, antimicrobial, Alzheimer's, hypoglycemic, cancer, antithrombin, Alzheimer's.

\section{I.Introduction}

The object of research is the creation of new settlements due to the creative work carried out in Kashkadarya region and the decoration of places with ornamental plants, landscaping at the expense of ornamental plants in accordance with local climatic factors.

The subject of the study is to increase the range of ornamental plants in accordance with the specific climatic conditions of Kashkadarya region, arid weather, hot summer, dry winter cold, low humidity, which begins in May.

\section{II.Literature review}

Under methods of research Prof. L.H. Yoziev's leadership, the number of ornamental trees and shrubs introduced in the oasis increased significantly. Propagation of Lagerstroemia indica L. belonging to the family Luthraceae (Luthraceae L.) is a similar ornamental plant. 
Scientific novelty of the study Natural and cultural area of Lagerstroemia indica L. introduced in Kashkadarya, use in agriculture, importance, pharmacological effect, composition of chemical compounds, components: alkaloids, cardiac glycosides, tannins, saponins, sterols, triterpenes, anthraquinones, reducing compounds results on anti-inflammatory, analgesic, antipyretic, antioxidant, anticancer, antimicrobial, anti-Alzheimer's, antidiabetic, hepatoprotective and antithrombin effects were studied.

\section{III.Analysis}

Representatives of this genus grow in tropical and subtropical countries in the form of small trees or shrubs. The great systematist Carl Linnaeus named the category after his friend Magnus V. Lagerstroem. There are 30 types in the category. Its 3 types are Lagerstroemia flos - regenae Retr, Lagerstroemia speciosa (Linn) Pers. and Lagerstroemia indica Linn. It is cultivated and cultivated in many countries of the subtropical region of the world [1]. (1 picture)

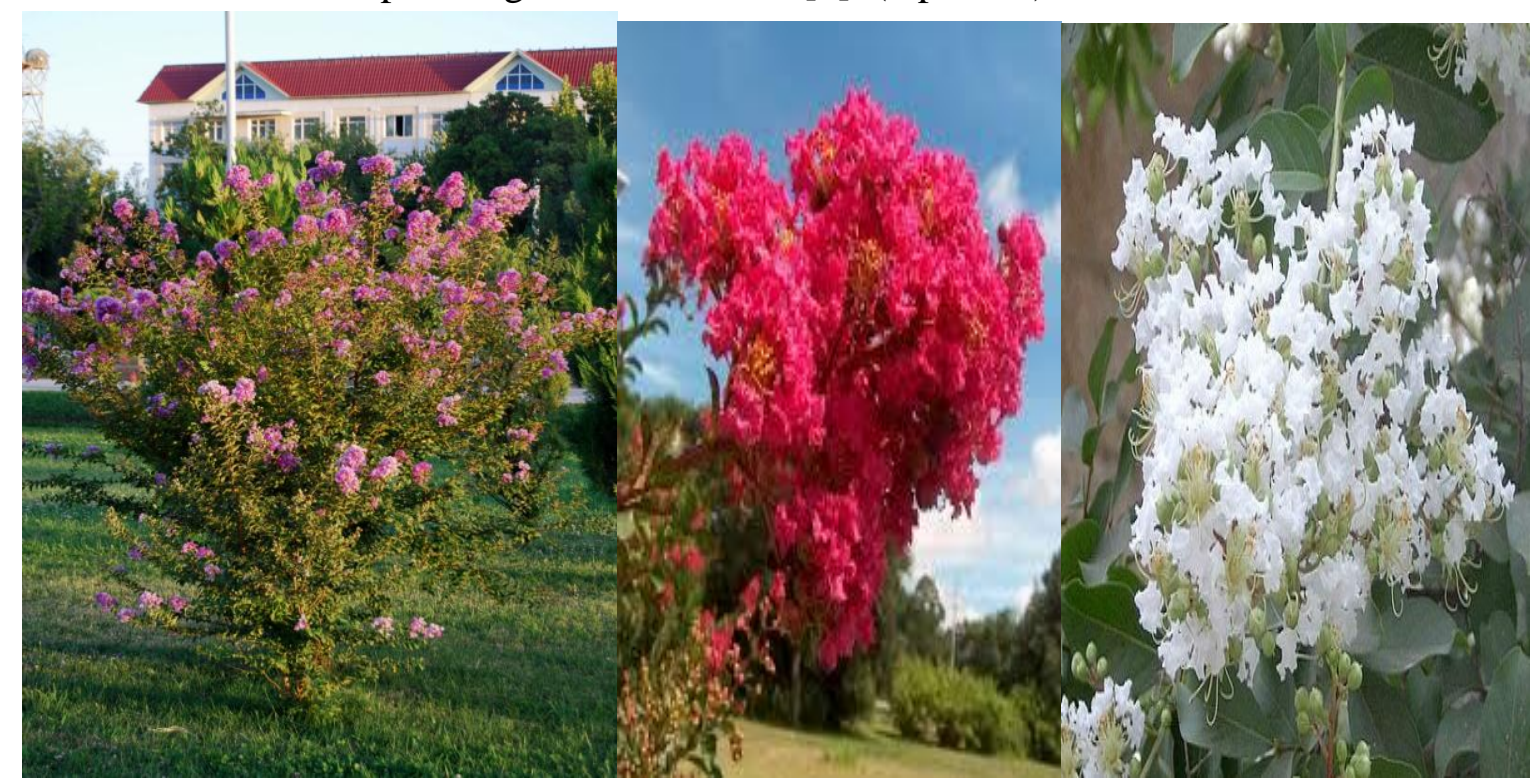

1 Picture. Lagerstroemia indica L. - Lagerstroemia (Lagerstoemia L.) belonging to the family Lythraceae Lindl L.

In the CIS countries, two species of the Lagerstroemia L. family - Lagerstroemia indica and Lagerstroemia speciosa - are common in adapted cultures, but only of these two species, Lagerstroemia indica, are culturally adapted [2].

Representatives of the Lagerstroemia L. family belong to a humid subtropical climate and are demanding on humidity and heat. Therefore, it is common in tropical and subtropical countries. There are 12 species of the genus in India, 3 species in Malaysia, as well as some species in Australia, Indochina, New Guinea and Madagascar. Some species are found in southern China $[3,4]$.

Lagerstroemia indica L. is natively found in Central and Southeast China, as well as in the region from South Korea to India, Japan, Taiwan, the Philippines, and a number of islands in Southeast Asia, as well as India [3,4]. (4 A. L. Korkeshko, 1968).

This species has Lagerstroemiya chinensis, Lagerstroemiya elegans, Lagerstroemiya indica, also known by synonyms such as alba, Lagerstroemiya pulchra, Murtughas indica, Velaga globosa, small lagerstremia, Banaba, Indian pride, divine flower. 
The world is also referred to in the scientific literature by the following names: Arabic: Ward elkahwa, Zahar kahwa katheb, Brenjik, Lailak hindi, Hinna hindi; Barazil: escumilha; Bengali: chhotojarul, purus, farash; Chinese: ziwei; English: Indian crape-myrtles, crepeflower, crepe-myrtle, Indian rose; French: Lilasdété, Lilas des Indes, Myrte de crêpe; German: Chinese Kräuselmyrte; $\underline{\text { Hindi }}$ : Farash, Harsingar, Furush, Saoni, Savani, Telingachina; Italy: Albero di San Bartolomeo, Lagerstremiya; Russian: Indian siren, Indian lagerstremia; Spain: Arbol de Jupiter, Crespon, Espumilla, Jupiter, Lila de LasIndias, Lila del sur, Melindres; Swedish: lagerströmiya; Turkish: It is called the Oyaağac1 [5].). Introduced in the conditions of Kashkadarya region, this species is distinguished by the fact that it creates a beautiful landscape among the introduced plants, the flowers are uniquely beautiful, unique, the petals are very diverse in color and bloom for a long time. The introduction of this unique and unusual, very rich shrub color of petals began long ago, in particular, propagated from the seeds of plants grown in the Batumi Botanical Garden and distributed in Batumi, Sukhumi, Tbilisi, Yerevan. Probably because the plants here are more adapted to climatic factors, they are widely grown as ornamental plants in the areas from the south of Crimea to Alushta, along the Black Sea from Tuapse to Batumi [6].

In Central Asia, it was first planted at the Ashgabat Forestry Experimental Station in 1928 as a 2-year-old sapling brought from the Crimea. Lagerstroemia indica L. is widely propagated and distributed in Turkmenistan. It has been planted in the Botanical Garden of the Academy of Sciences of Turkmenistan since 1937 from the Ashgabat Forestry. It was observed that the height of the specimen here reached $8 \mathrm{~m}$. Several years of experiments carried out under the conditions of introduction have shown that it can be propagated and distributed en masse [7].

The seeds were first brought to the Vakhsh regional station in Tajikistan in 1936 and grown from the United States. It has been grown in the Dushanbe Botanical Garden since 1951. Here, by sowing from 1961 seeds, red, reddish, pink, light pink and white drop varieties are grown [8]. For the first time in Tashkent in 1936-1939, mass reproduction was carried out, and these experiments yielded positive results.

Propagated and distributed, but most of these plants were affected by the cold winter of 1967-68. Some of these specimens are preserved in the Tashkent Botanical Garden. Currently, in the Tashkent Botanical Garden grows one specimen tree, 2-3 dwarf species. Also, 20 bushes of Lagerstroemia indica L. have survived and are growing and producing seeds in the alley near the Republic SSS building. From the seeds and cuttings given to us, the specimens grown by O.P. Pratov near the main building of the "Botanika" IBE and in the village of Humson, Bostanlyk district, are still growing.

In southern Uzbekistan, it was first air-conditioned in 1935 in Denau. [9]. Now it is grown in Bandikhan arboretum, Denau and Termez. Lagerstroemia indica L. was first planted in 1975 in Karshi, Kashkadarya region, as a 3-year-old seedling imported from Japan. Although this wonderful ornamental plant has long been of interest to many, no scientifically based experiments have been carried out on it. Prof. Yoziev L.H. under the guidance of the seeds imported from Denau in 1999, we began to propagate them without taking into account the agro-technical characteristics of the city of Karshi [11].

According to research, Lagerstroemia indica L. as a medicinal plant has various pharmacological effects, improves central nervous, cardiovascular, antioxidant, reproductive, gastrointestinal tract function, anti-diabetic, anti-cancer, anti-inflammatory, analgesic and antipyretic ( antipyretic), nephro (in the treatment of renal failure) and hepato (in the production of hepatoprotectors with cholecystitis 
and antispasmodic effect), the protector enriches liver function normally and improves digestion. The main alkaloids derived from it have analgesic, antispasmodic and antioxidant effects, extracts extracted from its composition help to regenerate hepatocytes and improve liver function. There are also data on the protective, urolithic and diuretic, antimicrobial and antiparasitic, antiprotozoal, fungal and insecticidal effects of the organism [12].

Lagerstroemia indica L. from the roots, bark, leaves and flowers of various parts of the plant has long been used in traditional folk medicine to control blood pressure, improve urinary function, as a strong diuretic, cleanses the kidneys, in the treatment of diarrhea, as an analgesic, cholesterol levels control, intestinal motility facilitator, widely used as a highly effective medicinal plant in the treatment of diabetes. The seeds have been used as potent sedative alkaloids (drugs). The bark and bark have been used as stimulants and antipyretics, the leaves and flowers as a body cleanser, the root binder and as a detoxifier (for the purpose of neutralizing various toxic chemicals) [13]. In the literature on the chemical composition of Lagerstroemia indica L., the presence of alkaloids, cardiac glycosides, tannins, saponins, sterols, triterpenes, anthraquinones, reducing compounds, flavonoids and phenolic glycosides (strotsides A-C), 22.53\% protein, carbohydrate $37,25 \%$ and ash $12.23 \mathrm{~g} \%$, mineral analysis data show that the plant contains large amounts of potassium, calcium, magnesium, phosphorus, sodium and sulfur. Phenolic derivatives isolated from the stem include: strotside A, B and C, 9, 9-dihydroxy-3, 4methoxylenedioxy-3-methoxy [7-O-4-8-5] -neolignan, dihydrodehydroconiferol alcohol, glucopyranoside, glycerol , glycopyranoside, glycol pyranoside, alatusol A, ficusol, evofolin-B, and marphenol. Also from the stem are triterpenes: lagerindicid, quadranoside, betulinic acid, 3bacetoxylene-12-en-28-acid, 28-O-glucopyranoside, oleanolic acid, fatty acid, 23-dihydroxy-1-oxo-olein12-en- 28-oxide acid separated from the stems.

\section{IV.Discussion}

A total of twenty-five types of phenolic substances were isolated from Lagerstroemia indica L. leaf extract. These substances include pyrogallol, gallic acid, 4-aminobenzoic acid, protocatchic acid, catechins, catechol, $\mathrm{n}$-hydroxy benzoic acid, chlorogenic acid, vanillic acid, n-coumaric acid, ferulic acid, iso-ferulic acid, vanillic acid, a- coumaric acid, benzoic acid, salicyl, pentacyclic triterpenoids and 3 beta-triol, 12-diene-3-hydroxy and lageflorin, biphenyl and biphenyl quinolysidine N-oxide alkaloids, decamine, dequinine, decodin, lageric derivative dihydrocyllate. Epidhydrolefolin 5 and its sterioisomer, dihydrolifolin, are isolated from the surface. Flavonoids luteolin-6-arabinose-8-glucose, luteolin-6-glucose-8-arabinose, apigenin-6-arabinose-8-glucose, apigenin-6-ramnose-8-glucose, apigenin-6-glucose-8-ramnoz, luteolin-7-glucose, hyperidine, rutin, apigenin, campherol, naringenin, campherol-3- (2-n-coumarol) glucose, gespertin, apigenin, apigenin-7-glucose, acacetin [14].

Pharmacological action: The fruits are multi-layered, from which ethanol extract has been found to have anti-inflammatory and antipyretic - antipyretic or stabilizing effect.

Toxicity. When the anti-tumor effects of evofolin-B compound, alatusol A, ficusol, and marphenol $\mathrm{C}$ murine compounds were studied, it was found that the extract obtained from the leaves helped to regenerate the tumor in the polysaccharide rat cage. The flowers of Indian camphor have been found to have high antioxidant cleansing activity in the body.

Anti-cancer effects: Ten triterpene glycosides isolated from the stem of Indian lagerstremia, strong cytotoxicity was detected in two phenol derivatives: A549 (non-small cell lung carcinoma), SK- 
OV-3 (malignant acid of the ovary), SK-MEL-2 (for NCT-15 (adeno carcinoma of the colon) and pterospermin A.

Antimicrobial effects: Methanol extract extracted from the leaves was evaluated for antimicrobial effects (Staphylococcus aureus (ATCC 8095), Salmonella enteritides (ATCC 13076), Escherichia coli (ATCC 25922), Listeria monocytogenes (ATCC 15C131) and ATCC 15313. .pure active compound exhibiting antimicrobial activity 4-methoxy apigenin-8-C-b-D-glucopyranoside; cycytoside and all tests have been shown to be effective against microorganisms.

Minimum concentration of killer mixture against Candida albicans (MLC $=32 \mathrm{mg} / \mathrm{ml}$ ), Staphylococcus aureus $(\mathrm{MLC}=16 \mathrm{mg} / \mathrm{ml}$ ), Salmonella enteritides $(\mathrm{MLC}=16 \mathrm{mg} / \mathrm{ml})$, Escherichia coli $(\mathrm{MLC}=16 \mathrm{mg} / \mathrm{ml}$ ) and Listeria at monocytogen (MLC $=16 \mathrm{mg} / \mathrm{ml})$. The antimicrobial activity of bark, leaves and fruits, ether, chloroform, methanol were studied Gram-positive (Staphylococcus aureus and Bacillus subtilis), two gram-negative (Escherichia coli and Pseudomonas aeruginosa) bacterial strains and two fungi (A. nigiger); . The maximum antibacterial effect of the bark (41.33 \pm $0.88 \mathrm{~mm}$ ) and the ethers of the leaves were found to have the maximum effect against Pseudomonas aeruginosa (49.33 $\pm 0.66 \mathrm{~mm})$ [15].

Against Alzheimer's disease: $80 \%$ rated on ethanol extract. Alzheimer's disease (AD) induced by aluminum chloride $(\mathrm{AlCl} 3)$ in mice. impaired levels of norepinephrine, acetylcholine esterase, dopamine, and serotonin in the results of treatment with leaf extract found a significant improvement in morbidity in rats caused by AD [16].

Hypoglycemic effect: The hypoglycemic effect of methanol in leaf extract was studied to reduce glucose levels in diabetic rats in polysaccharide (A extract) after 4 and 8 weeks, with glucose levels of $22.5 \%$ and $44.9 \%$, respectively, at $32.2 \%$ and $58.2 \%$, respectively at $\%$.

To determine antithrombin activity, chromogen, methylene chloride, and methanol extracts prepared from 30 plants in Florida have been shown to exhibit $80 \%$ or higher antithrombin activity when demonstrated.

When the toxicity level was studied, the mean lethal doses (LD50) of methanol leaf extract were studied in polysaccharides in mice, and the average lethal doses (LD50) were found to be 6.5 and $6.8 \mathrm{~g} /$ $\mathrm{Kg}$, respectively. [17]. The data show that in many countries of the world: China, Korea, Japan, India, Iran, Pakistan, Georgia and the United States, the medicinal properties of his whole body have been used. A sedative is obtained from the bark, leaves, flowers, which drive the fluid, and from the seeds, which have a rapid effect. The roots are used as a stimulant. Raw fruit is rich in hypoglycemic substance, which is equivalent to 6-7.7 $\mathrm{mg}$ of insulin. There is information on the use of fragrances in Lagerstroemia indica L. in the perfumery and cosmetics industry. Based on these properties, for the first time the chemical components of specimens grown in Kashkadarya conditions were studied.

Hence, the data presented show that all parts of Lagerstroemia indica L. are widely used for various purposes all over the world. Based on the data, the chemical composition of this species, which was introduced to Kashkadarya as a unique ornamental plant in order to enrich the region's gene pool, was analyzed for the first time in order to study its importance in the economy.

Introduced in the Kashkadarya oasis, Lagerstroemia indica L. was the first to study the component composition and chemical compounds of essential oils.

To do this, the dried leaves and flowers of the essential oils were shaken for $3 \mathrm{~h}$ in a glass tube and in a Clevenger nozzle and stored in a sealed ampoule at $4{ }^{\circ} \mathrm{C}$ until the sample obtained by 
hydrodistillation was analyzed. The resulting extract analysis was performed on Agilent 7890AGC gas chromatography, mass spectrum Agilent 5975S inert MSD quality detector.

Separation of components in the mixture HP-5MS $(30 \mathrm{~m} \times 250 \mu \mathrm{m} \times 0.25 \mu \mathrm{m})$ in the quartz capillary column Temperature regime: $500 \mathrm{C}(2 \mathrm{~min})$ - $100 \mathrm{C}$ (min to $2000 \mathrm{C}(6 \mathrm{~min})$ - from 150 / min to 2900 $\mathrm{C}$ (15 min) $1 \mathrm{ml}$ (hexane and benzene) phase flow rate of the sample $1.3 \mathrm{ml} / \mathrm{min}$. The mass spectra of the components were determined on the basis of comparison with the data of the electronic library W8N05ST.L i NIST08.

According to the results of the analysis, a total of 12 types of chemical compounds were isolated, and the largest of them were tsis-pinan (42.84\%), chloropyrifos (26.49\%), triacetylglycerin $(15.08 \%)$. The total amount of extracted components was $98.67 \%$ (Table 1).

Table - 1.

Chemical compounds in Lagerstoemia indica $L$.

\begin{tabular}{|c|c|c|c|c|}
\hline № & Name of components & $\mathrm{RI}^{*}$ & $\mathrm{VU}^{* *}$ & $\%$ \\
\hline 1 & 1,3,5-Trimethylbenzene & 995 & 6.018 & 1.27 \\
\hline 4 & n-Undekan & 1098 & 8.926 & 0.83 \\
\hline 5 & Pelargonaldehyde & 1104 & 9.123 & 0.77 \\
\hline 6 & n-Dodekan & 1127 & 12.086 & 1.59 \\
\hline 7 & 1,1-Dibutoxibutane & 1227 & 13.974 & 4.37 \\
\hline 8 & Triacetylglycerin & 1277 & 17.140 & 15.08 \\
\hline 9 & $\begin{array}{l}\text { 4,4,7a-trimethyl-5,6,7,7a- } \\
\text { tetrahydrobenzofuran- } 2 \\
(4 \mathrm{H}) \text {-on }\end{array}$ & 1528 & 22.520 & 1.49 \\
\hline 10 & tsis-Pinan & 1820 & 31.639 & $\begin{array}{c}42.8 \\
4\end{array}$ \\
\hline 11 & Neofitadien & 1837 & 32.703 & 3.94 \\
\hline 12 & Chlorpirifos & 1887 & 35.814 & $\begin{array}{c}26.4 \\
9\end{array}$ \\
\hline \multicolumn{4}{|c|}{$\Sigma$} & 98.67 \\
\hline
\end{tabular}

RI * - Bucket Index, VU ** - Hold time

\section{V.Conclusion}

Based on the above data, we plan to continue further research on the chemical compounds obtained and their importance, given that Lagerstroemia indica L. is rich in biologically active substances.

In conclusion, Lagerstroemia indica L. is fully vegetated in the introduced Kashkadarya conditions, and the chemical results obtained in this region show that the range of use of this species is very wide, but also in agriculture, medicine, pharmacology - anti-inflammatory, analgesic, antipyretic, antioxidant, anticancer, antimicrobial, Alzheimer's, antidiabetic, hepatoprotective and antithrombin effects. 


\section{References:}

1. Korkeshko A.L. Indian lagerstroemia (Lagerstroemia indica L.), its varieties and agricultural technology. Proceedings of the Sochi Nilos. Issue 5. 1968. pp. 231-247.

2. Shipchinsky N.V. Sem. Loose-Lychraceace Lindl. trees and shrubs SSR V.4. M: L Iz-vo USSR Academy of Sciences, 1958 pp. 907-910.

3. Yoziev L.Kh. Introduction of Indian lagerstremiya in the conditions of South Uzbekistan. Plant introduction and acclimatization. Issue 25. Tashkent: Fan, 1996, pp. 68-71.

4. Kuznetsova V.M. Collection of Indian lagerstremia in the Nikitsky Botanical Garden. Bull. State Nikit. Botanical garden. Issue 8. Tashkent: fan, 1987. pp 34-38.

5. Ali Esmail Al-Snafi A Review on Lagerstroemia Indica: A Potential Medicinal Plant. IOSR Journal Of Pharmacy www.iosrphr.org . (e)-ISSN: 2250-3013, (p)-ISSN: 2319-4219. Volume 9, Issue 6 Series. II (June 2019), PP. 36-42

6. Jackalo N.I. Introduction of trees and shrubs in the flora of East Asia. Plant introduction and ecology. Ashkhabad: Ilm 1981.pp. 37-63.

7. Muratgeldiev N. Lagerstroemia indica in Ashgabat. Bul. Chapters Nerd. Sada, issue 64.1967.

8. Vilisova V.V., Zapryagaeva V.I., Zelyaeva Z.R., Rokochaya E.K., Temberg Y.G. Trees and shrubs. Plants for decorative gardening in Tajikistan. M. Nauka, 1986, pp. 88-367.

9. Lopott M.S., Indian lilac. Bul. For crops of dry subtropics No. 9-10 (45-46). August 1939 Stalinabad., 52-56 p.

10. Kulkov O. P. Introduction of trees and shrubs in the south of Uzbekistan Bul Glav. Nerd. Garden. Issue 58.1965. pp. 30-33.

11. Sharopova MA On the ecological features of air-conditioned camping in southern Uzbekistan. Tashkent. 2000, pp. 73-75.

12. Al-Snafi AE, Talab TA and Majid WJ. Medicinal plants with central nervous activity - An overview (Part 1). IOSR Journal of pharmacy 2019, 9(3): 52-102.

13. Ashnagar A, Ghanad AR and Motakefpour M. Isolation and identification of major chemical components found in the leaves of Lagerstroemia indica plant grown in the city of Tehran, Iran. Int J ChemTech Res 2013; 5(1):478-481.

14. Vankar PS and Srivastava J. Evaluation of anthocyanin content in red and blue flowers. International Journal of Food Engineering 2010; 6(4), doi: 10.2202/ 1556-3758.1907

15. Milad R, Ayoub NA, Singab A, Al-Azizi MM and Sleem A. Chemical constituents and pharmacological studies of Lagerstroemia indica. Phytopharmacology 2013; 4(2): 373-389.

16. Lee BJ, Kim JH, Ham SJ and Lee CE. Study on biological activities of extracts for cosmeceutical development from Lagerstroemia indica L. branch. Korean Journal of Plant Resources 2014; 27(1): 29- 34.

17. Elsawi SA, Aly HF, Elbatanony MM, Maamoun AA and Mowawad DM. Phytochemical evaluation of Lagerstroemia indica (L.) Pers leaves as anti-Alzheimer's. J Mater Environ Sci 2018; 9(9): 2575-2586. 